HABITAT, 32 (2), 2021, 63-73

DOI: 10.21776/ub.habitat.2021.032.2.8

\title{
Hierarchy Analysis, Leading Commodities and Community Participation in Agropolitan Areas in Trenggalek Regency, East Java Province
}

\author{
Angga Pratama Putra ${ }^{*}$, Budi Setiawan ${ }^{2}$, Suhartini $^{2}$ \\ Department of Agriculture Economics, Faculty of Agriculture, Brawijaya University, St. Veteran, Malang \\ (65145), Indonesia.
}

Received: 14 October 2020; Revised: 21 May 2021; Accepted: 24 June 2021

\begin{abstract}
The agropolitan area in Trenggalek Regency is one of the regional development programs that began in 2006. The objectives of this study are 1) Determining the hierarchical structure of growth and service centers in an agropolitan area, 2) Determining superior commodities that can be developed in an agropolitan area, 3) Knowing perceptions and levels of community participation as well as the factors that influence it in an effort to increase active community participation as the main actor in agropolitan area development. The research location was determined purposively. This study uses two types of data, namely primary data and secondary data. The analytical methods used in this research are 1) scalogram analysis, 2) Location Quotient / LQ analysis, 3) non-parametric chi-square statistical analysis. Based on the schalogram analysis of villages in the agropolitan area in Trenggalek Regency, it is obtained a hierarchy of regions in the agropolitan area in Trenggalek Regency, so that Tasikmadu, Pule, Jombok and Sumurup Villages are the centers of growth and service centers while the development areas of Karanggandu Village, Prigi, Watulimo, Sawahan, Watuagung, Sidomulyo, Tanggaran, and Dompyong are agropolitan areas. While other development areas, namely the Dukuh, Slawe, Gemaharjo, Pakel, Ngembel, Puyung, Joho, Kembangan, Pakel, Masaran, Sengon, Srabah, Surenlor and Botoputih development areas are hinterland areas. Based on the results of the LQ analysis, the agropolitan area in Trenggalek Regency has 34 (thirteen) commodities that have an LQ value of more than 1: leaves, potatoes, mustard greens, long beans, large chilies, bird's eye chilies, green beans and chayote, c) Fruit crop subsectors: avocado, star fruit, duku, durian, guava, water guava, orange siem, large orange, mangosteen, jackfruit, papaya, rambutan, salak, sapodilla and soursop, d) Sub-sector of plantation crops: Patchouli, sugarcane, cocoa, cloves, coffee, vanilla and cottonwood. The level of public perception towards agropolitan programs is relatively poor. The level of community participation in agropolitan programs is relatively low. The intrinsic factors that have a real influence on the level of participation are income and land area, while the extrinsic factors are socialization, assistance, openness of government, program suitability and benefits. Increasing community participation can be done by improving the factors that have a real influence.
\end{abstract}

Keywords: agropolitan; hierarchy; superior; commodity; perception

\section{How to cite:}

Putra, A. P., Setiawan, B., \& Suhartini. (2021). Hierarchy Analysis , Leading Commodities and Community Participation in Agropolitan Areas in Trenggalek Regency, East Java Province. HABITAT, 32(2), 6373. https://doi.org/10.21776/ub.habitat.2021.032.2.8

\section{Introduction}

The agropolitan program began in 2002 with a pilot in 8 districts, in its development until 2005 at least more than 98 districts in 33 provinces held this agropolitan program. One of the districts in East

${ }^{*}$ Correspondence Author.

E-mail: anggabest94@gmail.com
Java Province that is being developed as an agropolitan area is Trenggalek Regency. Until 2018, the number of Agropolitan areas in Trenggalek Regency was 3 sub-districts. As a development area, it is hoped that an agropolitan area can become a new growth area that can contribute to regional development and increase community welfare, both for the benefit of the region itself and to the wider agropolitan area around it. Leading commodities are 
mainstay commodities that have a strategic position based on technical considerations (soil and climate conditions) as well as socio-economic and institutional conditions (mastery of technology, human resource capacity, infrastructure and local socio-cultural conditions). Agropolitan development is carried out by empowering the community to be able to develop superior commodity businesses based on the suitability of land capabilities and regional socio-cultural conditions. Community empowerment is not only directed at increasing the production and productivity of agricultural commodities but also at developing businesses with other agribusiness systems that support superior commodity agribusiness in agropolitan areas, namely upstream agribusiness, downstream agribusiness (marketing, product processing, sorting and grading) as well as service industries and service. The success of implementing an agropolitan program is determined by the involvement of all stakeholders together. One of them is community involvement and participation (Baskoro, 2007; Brata, 2013; Citraningrum, 2009; Efendi, 2017). This is because development is basically an empowerment process that has the aim of improving community welfare (Baskoro, 2007). Thus the community is the main actor in the development process, not just an object. Meanwhile, from the social point of view, an analysis of community perceptions and participation was carried out on the agropolitan area development program. From the various descriptions above, several problems can be formulated in this study: 1) How can the hierarchical structure in an agropolitan area with a growth center and hinterland area be able to provide an optimal development impact? Which superior commodities can be developed and become prime movers for an agropolitan area? 3) What is the level of community perception and participation in the development of an agropolitan area? What are the factors that have a significant relationship in the effort to increase the active participation of the community as the main actors of agropolitan area development?

\section{Research Methods}

The research location was determined purposively. Trenggalek Regency as the location chosen in this study, with the consideration that most of Trenggalek Regency is rural and agricultural as the economic base, and is one of the districts that is pioneering regional development based on the Agropolitan concept. The agropolitan area in Trenggalek Regency consists of Bendungan, Watulimo and Pule Districts. The research was conducted for 2 months, from March to April 2018.

This study used two types of data, namely primary data and secondary data. Primary data were obtained and collected directly from respondents and key informants in the Agropolitan area of Trenggalek Regency. Meanwhile, secondary data is data obtained from related agencies that are available in the form of documents and literature studies.

There are 239 (two hundred thirty nine) farmer groups in the agropolitan area in Trenggalek Regency, which consist of 41 (forty one) farmer groups in the growth center villages, namely Tasikmadu, Pule, Jombok and Sumurup villages while 198 (one hundred and ninety eight) farmer groups are located in hinterland villages. The selection of respondents was carried out randomly stratified (cluster random sampling) to the location of the respondents, namely in the center of growth villages and hinterland villages. The respondent is the head of a farmer group located in an agropolitan area in Trenggalek Regency. The determination of the number of respondents is based on Larry King's monogram where with an error rate of $10 \%$ (Baskoro, 2007) and a population of 239, the sample that should be used is $30 \%$. Thus the respondents taken were $30 \%$ of the population of 239 farmer groups, amounting to 72 (seventy two). With the stratification of the location of the respondents' residence by taking into account the number of farmer groups in the growth center and hinterland areas, the distribution of the sample of respondents is obtained, consisting of 13 (thirteen) respondents in the growth center villages and 59 (fifty nine) respondents in the hinterland villages. The stratified farmer groups were then randomized and the number was taken according to the existing sample. Meanwhile, the respondent in this study was the head of a farmer group that had been subjected to statification and randomization.

To analyze the growth centers in the Agropolitan Area in Trenggalek Regency, this study uses 6 main categories which are considered capable of representing the needs of the local population. The 6 categories used are as follows: 
a. Educational infrastructure which includes school facilities ranging from kindergarten to senior high school (SMA).

b. Economic infrastructure which includes facilities for cooperatives, banks, markets and slaughterhouses (RPH).

c. Health infrastructure, which includes public hospital facilities, health centers and auxiliary health centers.

d. Communication and transportation facilities which include post offices, terminals and stations.

e. Community infrastructure which includes facilities for worship, orphanages and clean water facilities.

f. Agricultural infrastructure, which includes the existence of a rice mill and the availability of tractors in each region.

After grouping the required data according to the main categories, the next step is to compile the index value of each facility so that the sub-district development index value is obtained which will later be used to determine the service center or growth center in the Agropolitan Area of Trenggalek Regency. The stages in the preparation of the index value are as follows :

\section{1) Rationalization}

Rationalization is the stage of changing facility data (number of facilities) in a village into capacity data. Capacity data is obtained by dividing data on facilities in a village by the number of residents. For more details, see the example below

Capacity of SMA Village A

$$
=\frac{\text { Number SMA of facilities in the Village A }}{\text { Number of Villager A }}
$$

\section{2) Weighting}

The second stage is weighting. Weighting is done by dividing the total facility capacity in one village by the number of areas that have these facilities. Then divide the capacity data by the weight of village facilities. For more details, see the calculation example below:

$$
\begin{aligned}
& \text { Weighting } \\
& =\frac{\text { Total SMA capacity }}{\text { The number of villages that have SMA facilities }} \\
& \text { Weight per facility of district } \\
& =\frac{\text { Capacity SMA Village A }}{\text { Facility weights }}
\end{aligned}
$$

3) Standardizaton

The next stage is to carry out the standardization stage. Data standardization is done by reducing the weight data for village facilities with the minimum weight value, then dividing by the standard deviation of the weight value per village. For more details, it can be seen mathematically below:

$$
Y i j=\frac{X i j-\min X i j}{S j}
$$

Information:

Yij: Value of Standardization Results

Xij: Facility weights

$\mathrm{Sj}$ : Standard Deviation

\section{4) Addition}

The last stage is to add up the standardization values generated in the previous stage. The sum of the standardized values is then used as the Village Development Index (IPD). The grouping of service centers or growth centers and hinterland areas is based on the following categories:

High (Hierarki I) : X $>$ mean +2 (Standard Deviation IPD)

Medium (Hierarki II) : Mean $\leq \mathrm{X} \leq$ 2(Standard Deviation IPD)

Low (Hierarki III) :X $<$ Mean

From the results of the schalogram with the hierarchical index, a village hierarchy can be determined, where villages that have a high level of development have the potential as growth centers and service centers, while villages with moderate and low levels of development tend to be hinterland areas. Development with a growth center or service center is the implementation of development based on the application of the agropolitan concept.

To analyze superior commodities using the relevant Location Quotient (LQ) technique, it is used as a method in determining superior commodities, especially from the supply side (production or population). For land-based commodities such as food crops, horticulture and plantations, the calculation is based on agricultural land (planted area or harvested area), production or productivity.

In the LQ application towards obtaining superior commodities based on the aspect of harvested area, it is defined that LQ is the ratio between the relative share of the harvested area for 
commodity $\mathrm{i}$ at the regional level to the total harvested area in the sub-sector of the region with the relative share of the harvested area for commodity $\mathrm{i}$ at the national level to the total harvested area in the national sub-sector. Mathematically, the LQ formula is written as follows:

Where:

$$
L Q=\frac{P i t}{\text { Pit }}
$$

Pit $=$ share of commodity harvest area $i$ at the subdistrict level $\mathrm{t}$

Pit $=$ share of the harvest area for commodity $i$ at the district level

Operationally the LQ formulation is written as follows:

$$
L Q=\frac{P i / P t}{P i / P t}
$$

Where:

$\mathrm{Pi}=$ harvest area for commodity $\mathrm{i}$ at the kecamatan level

$\mathrm{Pt}=$ total harvested area for commodity i sub-sector at the sub-district level

$\mathrm{Pi}=$ harvested area for commodity $\mathrm{i}$ at the district level

$\mathrm{Pt}=$ total harvested area for commodity i subsector at the district level

The results of the LQ calculation produce three (3) criteria, namely:

a) LQ> 1, which means that the commodity becomes a base or a source of growth. Commodities have a comparative advantage, the results are not only able to meet the needs of the region but can also be exported outside the region.

b) $\quad \mathrm{LQ}=1$; the commodity is classified as nonbasis, it does not have a comparative advantage. Its production is only sufficient to meet the needs of the region itself and cannot afford to be exported.

c) $\quad$ LQ $<1$; this commodity is also a non-basis. Commodity production in a region cannot fulfill its own needs so it needs supplies or imports from outside.

In this study, people's perceptions of the agropolitan program were measured by indicators covering three aspects, namely: I) cognitive aspects emphasizing knowledge and people's views, 2) affective aspects emphasizing feelings, emotions and interests, 3) conative aspects emphasizing the desire to act or do something about a response that can support an agropolitan program. The stages in the preparation of the index value are as follows
a. Rationalization.
b. Weighting.
c. Standardization.
d. Addition.

The last stage is to add up the standardization values generated in the previous stage. The sum of the standardized values is then used as the level of public perception. The level of community perception is based on the following categories:

Good : $\mathrm{X}>$ mean

Bad :X $<$ Mean

To analyze the level of community participation in the Agropolitan Area in Trenggalek Regency, this study used four stages, namely participation in planning and decision making, participation in implementation, participation in monitoring and evaluation, and participation in sharing benefits. After grouping the required data according to the 4 stages, the next step is to compile the score for each stage so that the score will be obtained which will be used to determine the level of community participation in the Agropolitan Area of Trenggalek Regency. The stages in the preparation of the index value are as follows
a. Rationalization.
b. Weighting.
c. Standardization.
d. Addition

The last stage is to add up the standardization values generated in the previous stage. The sum of the standardized values is then used as the level of public perception. The level of community perception is based on the following categories:

High : $X>$ mean

Low :X $<$ Mean

Community perceptions that have been measured are then analyzed using the chi-square non-parametric statistical method to determine the relationship between location and type of commodity and the level of community perception. The location where the respondent lives is divided into 2, namely:

a. residing in a growth center village;

b. residing in a hinterland village.

The commodities cultivated by the respondents were divided into 4 groups. that is :

1) Rice fields with the main commodities of rice and soybeans; 
2) Tegalan 1 with the main commodities of cassava and corn;

3) Tegalan 2 with the main commodities of star fruit, duku, durian, guava, guava, oranges, mangosteen, jackfruit, papaya, rambutan, salak, sapodilla and sirsat

4) Plantations with the main commodities of patchouli, sugar cane, cocoa, cloves, coffee, vanilla and cottonwood

\section{Results and Discussion}

\subsection{Determination of Growth Centers and Service Centers}

The agropolitan area in Trenggalek Regency consists of 3 districts, namely Watulimo District, Pule District and Bendungan District. Of the three sub-districts, there are 30 (thirty) villages that have various characteristics, public facilities and facilities and infrastructure. The village system shows the distribution of villages in a certain area arranged according to the order based on the village development index, so that it can show a ranking or hierarchy of villages. The greater the village development index, the stronger the role (dominance) and the level of priority of a village against other villages or areas at a lower level. High hierarchical villages have the potential to become centers of growth and service centers for the region. Based on the schalogram analysis of the villages in the agropolitan area in Trenggalek Regency, the village hierarchy in the agropolitan area is obtained, as shown in Table 1.

Table 1. Results of schalogram analysis based on standardized village development index

$\begin{array}{llrl}\text { Pakel } & \text { Watulimo } & 6,85 & 3 \\ \text { Ngembel } & \text { Watulimo } & 3,88 & 3 \\ \text { Watuagung } & \text { Watulimo } & 16,67 & 2 \\ \text { Sidomulyo } & \text { Pule } & 18,96 & 2 \\ \text { Puyung } & \text { Pule } & 10,96 & 3 \\ \text { Joho } & \text { Pule } & 11,21 & 3 \\ \text { Kembangan } & \text { Pule } & 3,87 & 3 \\ \text { Pakel } & \text { Pule } & 9,34 & 3 \\ \text { Pule } & \text { Pule } & 37,32 & 1 \\ \text { Jombok } & \text { Pule } & 32,22 & 1 \\ \text { Tanggaran } & \text { Pule } & 15,04 & 2 \\ \text { Karanganyar } & \text { Pule } & 13,85 & 3 \\ \text { Sukokidul } & \text { Pule } & 9,51 & 3 \\ \text { Masaran } & \text { Bendungan } & 3,69 & 3 \\ \text { Sengon } & \text { Bendungan } & 6,38 & 3 \\ \text { Sumurup } & \text { Bendungan } & 27,96 & 1 \\ \text { Srabah } & \text { Bendungan } & 5,41 & 3 \\ \text { Depok } & \text { Bendungan } & 18,63 & 2 \\ \text { Surenlor } & \text { Bendungan } & 12,47 & 3 \\ \text { Dompyong } & \text { Bendungan } & 19,51 & 2 \\ \text { Botoputih } & \text { Bendungan } & 14,78 & 3\end{array}$

The results of the schalogram analysis show that the growth center villages or service center villages in the agropolitan area of Trenggalek Regency are Tasikmadu, Pule, Jombok and Sumurup villages. The other 26 villages are in hierarchy 2 and 3, which tend to be hinterland villages or support villages (Badan Perencanaan Pembangunan Daerah Kabupaten Trenggalek, 2018).

\subsection{Identification of Leading Commodities}

Agricultural commodities are divided according to their sub-sectors, namely agriculture of food crops, vegetables, fruits and plantations. The agropolitan area in Trenggalek Regency has the

\begin{tabular}{|c|c|c|c|c|}
\hline Village & District & $\begin{array}{l}\text { Development } \\
\text { Index }\end{array}$ & Hierarchy & $\begin{array}{l}\text { agropolitan area in Trenggalek Regency has the } \\
\text { potential and development of the agricultural sector. }\end{array}$ \\
\hline Karanggandu & Watulimo & 17,62 & 2 & \\
\hline Prigi & Watulimo & 20,65 & 2 & sector that has the low \\
\hline Tasikmadu & Watulimo & 31,63 & 1 & ors. To increase the role of the \\
\hline Watulimo & Watulimo & 20,34 & 2 & ctor, it is necessary to 10 \\
\hline Margomulyo & Watulimo & 19,29 & 2 & Ommodiles which, il deveroped, \\
\hline Sawahan & Watulimo & 17,22 & 2 & vers of the regional econon \\
\hline Dukuh & Watulimo & 8,25 & 3 & \\
\hline Slawe & Watulimo & 7,58 & 3 & \\
\hline Gemaharjo & Watulimo & 14,96 & 3 & \\
\hline
\end{tabular}


Table 2. Results of LQ analysis for agricultural commodities

\begin{tabular}{|c|c|c|c|c|}
\hline \multirow{2}{*}{ Sub Sector } & \multirow{2}{*}{ Commodity } & \multicolumn{3}{|c|}{ District } \\
\hline & & Watulimo & Pule & Bendungan \\
\hline \multirow{4}{*}{ Food Crops } & Rice & 0,56 & 1,05 & 0,64 \\
\hline & Corn & 2,35 & 1,32 & 1,32 \\
\hline & Soybeans & 1,48 & 0,11 & 1,27 \\
\hline & Cassava & 0,32 & 0,89 & 1,61 \\
\hline \multirow{8}{*}{ Vegetable Crops } & Leeks & 0,00 & 2,21 & 3,29 \\
\hline & Potatoes & 0,00 & 8,10 & 0,00 \\
\hline & Mustard greens & 0,00 & 1,08 & 0,00 \\
\hline & Long bean & 3,71 & 0,68 & 1,21 \\
\hline & Large chilies & 1,24 & 0,41 & 0,00 \\
\hline & Cayenne pepper & 1,44 & 0,39 & 0,88 \\
\hline & Green beans & 0,00 & 2,40 & 2,01 \\
\hline & Chayote & 2,47 & 2,84 & 1,81 \\
\hline \multirow{15}{*}{ Fruit Crops } & Avocado & 0,07 & 1,41 & 5.50 \\
\hline & Star fruit & 0,33 & 2,91 & 0,00 \\
\hline & Duku & 1,71 & 0,00 & 0,00 \\
\hline & Durian & 2,27 & 0,64 & 0,00 \\
\hline & Guava & 0,12 & 15,21 & 0,00 \\
\hline & Water guava & 1,06 & 5,56 & 0,00 \\
\hline & Siam Orange & 3,74 & 5,90 & 0,00 \\
\hline & Big Orange & 1,94 & 0,00 & 0,00 \\
\hline & Mangosteen & 2,93 & 1,30 & 0,46 \\
\hline & Jackfruit & 0,59 & 5,47 & 1,39 \\
\hline & Papaya & 0,00 & 2,06 & 1,38 \\
\hline & Rambutan & 0,00 & 0,00 & 1,52 \\
\hline & Salak & 3,99 & 0,38 & 0,00 \\
\hline & Sapodilla & 0,00 & 2,15 & 0,00 \\
\hline & Soursop & 0,00 & 4,89 & 1,25 \\
\hline \multirow{7}{*}{ Plantation Crops } & Patchouli & 0,70 & 1,93 & 2,22 \\
\hline & Sugarcane & 0,21 & 1,46 & 0,00 \\
\hline & Cocoa & 0,81 & 1,66 & 1,00 \\
\hline & Cloves & 1,40 & 2,16 & 1,32 \\
\hline & Coffee & 1,29 & 1,37 & 3,77 \\
\hline & Vanilla & 1,78 & 1,97 & 0,00 \\
\hline & Cottonwood & 0,00 & 2,78 & 3,21 \\
\hline
\end{tabular}

Based on the results of the LQ analysis, the agropolitan area in Trenggalek Regency has 34 (thirty four) commodities that have an LQ value of more than 1, namely:

a. Food crops sub-sector: Rice, corn, soybeans and cassava.

b. Vegetable sub-sector: Leeks, potatoes, mustard greens, long beans, large chilies, cayenne pepper, green beans and chayote. c. Fruit crops sub-sector: avocado, star fruit, duku, durian, guava, water guava, siem orange, big orange, mangosteen, jackfruit, papaya, rambutan, salak, sapodilla and soursop.

d. Sub-sector of plantation crops: Patchouli, sugarcane, cocoa, cloves, coffee, vanilla and cottonwood.

A leading commodity is identified with an LQ value greater than 1 . An LQ value greater than 1 
indicates the ability to produce certain commodities and the ability to supply to other regions because the share is relatively larger compared to the production of other commodities.

\subsection{Perception and Public Participation in the Development of Agropolitan Areas and Factors Affecting Them}

A person's level of perception is influenced by three factors, namely cognitive, affective and conative (Baskoro, 2007; Endaryanto, 1999; Yulida, 2002). Based on the results of the questionnaire, it can be done tabulation of the level of community perception of the development of agropalitan areas in Trenggalek Regency as shown in the following table.

Table 3. The tabulation results of the respondent's perception level

\begin{tabular}{lccc}
\hline Participation & \multicolumn{3}{c}{ Respondent } \\
\cline { 2 - 4 } & Hierarchy & Hierarchy & Hierarchy \\
& $\mathbf{1}$ & $\mathbf{2}$ & $\mathbf{3}$ \\
\hline Good & 13 & 8 & 4 \\
Buruk & 0 & 16 & 31 \\
\hline Total & 13 & 24 & 35 \\
\hline (Source: Primary
\end{tabular}

(Source: Primary data, processed)

From the table above, it can be seen that respondents who are in hierarchy 1 have a better Perception Level than hierarchies 2 and 3 . This is in accordance with research conducted by Baskoro, 2007; Brata, 2013; Efendi, 2017 that people who are in hierarchy 1 have a better level of perception than people in hinterland areas. Meanwhile, to determine the relationship between the location of residence and cultivated commodities with the level of perception, the chi-square analysis was used. The location where the respondents live is divided into the growth center village and the hinterland village. Meanwhile, cultivated commodities are divided into four groups, namely:

a. Rice fields with the main commodities of lowland rice and soybeans;

b. Tegalan 1 with the main commodities of cassava and corn;

c. Tegalan 2 with the main commodities of star fruit, duku, durian, guava, guava, oranges, mangosteen, jackfruit, papaya, rambutan, salak, sapodilla and tailings.

d. Plantations with the main commodities of patchouli, sugar cane, cocoa, cloves, coffee, vanilla and cottonwood.

Based on the chi-square analysis with $t$ count $5 \%$, the result shows that there is a significant relationship between the location where the respondent lives and the commodities cultivated with the respondent's level of perception. This is consistent with research conducted by Baskoro, 2007; Brata, 2013; Efendi, 2017.

Table 4. The results of the chi square analysis of the relationship between location and commodity and perception

a. Location of residence

Chi-Square Tests

\begin{tabular}{lccccc}
\hline & Value & df & $\begin{array}{c}\text { Asymptotic } \\
\text { Significance (2-sided) }\end{array}$ & $\begin{array}{c}\text { Exact Sig. } \\
\text { (2-sided) }\end{array}$ & $\begin{array}{c}\text { Exact Sig. } \\
\text { (1-sided) }\end{array}$ \\
\hline Pearson Chi-Square & $29.825^{\mathrm{a}}$ & 1 & .000 & & \\
Continuity Correction & 26.414 & 1 & .000 & & \\
Likelihood Ratio & 33.384 & 1 & .000 & .000 & .000 \\
Fisher's Exact Test & & & & & \\
Linear-by-Linear Association & 29.411 & 1 & .000 & & \\
\hline N of Valid Cases & 72 & & & \\
\hline
\end{tabular}

b. A cultivated commodity

Chi-Square Tests

\begin{tabular}{lcccc}
\hline & Value & df & Asymptotic Significance (2-sided) \\
\hline Pearson Chi-Square & $13.293^{\mathrm{a}}$ & 3 & .004 \\
Likelihood Ratio & 16.486 & 3 & .001 \\
Linear-by-Linear Association & .943 & 1 & .332 \\
\hline N of Valid Cases & 72 & & \\
\hline
\end{tabular}

Available online at HABITAT website: http://www.habitat.ub.ac.id

ISSN: 0853-5167 (p); 2338-2007 (e) 
Respondents who are located in the central village of growth / development areas tend to have a better perception than respondents who are in hinterland areas. Likewise, differences in the types of cultivated commodities have a significant relationship or influence on the level of respondents' perceptions, where respondents who cultivate rice fields, moor 1 and moor 2 commodities have a better perception than respondents who cultivate rice fields, dry 1, 2 and plantations.

The level of participation is influenced by planning, implementation, monitoring and benefits (Baskoro, 2007; Harahap, 2001). The results of tabulation of the level of community participation in the development of agropolitan areas in Trenggalek Regency can be described in the following this table.

Table 5. The tabulation results of the respondent's participation level

\begin{tabular}{|c|c|c|}
\hline \multirow[t]{2}{*}{ Participation } & \multicolumn{2}{|c|}{ Respondents } \\
\hline & Total & Persentage \\
\hline High & 25 & 34,72 \\
\hline Low & 47 & 65,28 \\
\hline Total & 72 & 100,00 \\
\hline
\end{tabular}

participation of respondents to the agropolitan program was relatively low, namely as many as 47 respondents or reaching $65.28 \%$ and only 25 respondents or as many as $34.72 \%$ who had high participation. This result is in line with the results of the perception analysis, where people in agropolitan areas have low perceptions and participation of agropolitan programs. These results are consistent with research conducted by Baskoro, 2007.

There are two factors that influence the relationship or significant influence on the level of participation, namely internal factors and external factors (Baskoro, 2007; Pujo, 2003). The results of the chi-square analysis of the factors affecting participation with $\mathrm{t}$ count of $5 \%$ as in the table indicate that the factors that are significantly related to the level of community participation are:

a. Internal factors: income and land area.

b. External factors: institutions, open government, socialization, assistance, program suitability and benefits.

The factors of income and land area are interrelated, the more land is cultivated, the more income tends to increase. The greater the income, the more income can be contributed to facilitate the activities being carried out or the participation tends to be large. The results of the study are in accordance with research conducted by Baskoro, 2007 and Lestari, 2019 that there is a significant relationship to the level of participation, including land ownership, income and cosmopolitanism, while age, education level, length of stay and stakeholders are not significantly related.

Table 6. The results of the chi square analysis of the relationship between the level of participation and the factors that influence it

\begin{tabular}{lccc} 
a. Age & & & \\
\hline \multicolumn{1}{c}{ Chi-Square Tests } & Value & df & Asymptotic Significance (2-sided) \\
\hline Pearson Chi-Square & $9.339^{\mathrm{a}}$ & 2 & .009 \\
Likelihood Ratio & 9.185 & 2 & .010 \\
Linear-by-Linear Association & 7.607 & 1 & .006 \\
\hline N of Valid Cases & 72 & & \\
\hline
\end{tabular}

b. Education

\begin{tabular}{lccc}
\hline \multicolumn{1}{c}{ Chi-Square Tests } & Value & df & Asymptotic Significance (2-sided) \\
\hline Pearson Chi-Square & $.735^{\mathrm{a}}$ & 2 & .693 \\
Likelihood Ratio & .717 & 2 & .699 \\
Linear-by-Linear Association & .620 & 1 & .431 \\
\hline N of Valid Cases & 72 & & \\
\hline$\quad$ c. Land area & & & Asymptotic Significance (2-sided) \\
\hline \multicolumn{1}{c}{ Chi-Square Tests } & Value & df & .001 \\
\hline Pearson Chi-Square & $14.551^{\mathrm{a}}$ & 2 & .001 \\
Likelihood Ratio & 14.842 & 2 & .001 \\
Linear-by-Linear Association & 11.735 & 1 & \\
\hline N of Valid Cases & 72 & & \\
\hline
\end{tabular}

Available online at HABITAT website: http://www.habitat.ub.ac.id

ISSN: 0853-5167 (p); 2338-2007 (e) 
d. Income

\begin{tabular}{lccc}
\hline \multicolumn{1}{c}{ Chi-Square Tests } & Value & df & Asymptotic Significance (2-sided) \\
\hline Pearson Chi-Square & $11.238^{\mathrm{a}}$ & 2 & .004 \\
Likelihood Ratio & 13.163 & 2 & .001 \\
Linear-by-Linear Association & 10.865 & 1 & .001 \\
\hline N of Valid Cases & 72 & & \\
\hline
\end{tabular}

e. Instutional

\begin{tabular}{|c|c|c|c|c|c|}
\hline Chi-Square Tests & Value & df & $\begin{array}{c}\text { Asymptotic Significance } \\
\text { (2-sided) }\end{array}$ & $\begin{array}{l}\text { Exact Sig. } \\
\text { (2-sided) }\end{array}$ & $\begin{array}{l}\text { Exact Sig. } \\
\text { (1-sided) }\end{array}$ \\
\hline Pearson Chi-Square & $9.182^{\mathrm{a}}$ & 1 & .002 & \multirow{5}{*}{.003} & \multirow{5}{*}{.002} \\
\hline Continuity Correction ${ }^{\mathrm{b}}$ & 7.626 & 1 & .006 & & \\
\hline Likelihood Ratio & 10.584 & 1 & .001 & & \\
\hline Fisher's Exact Test & & & & & \\
\hline Linear-by-Linear Association & 9.055 & 1 & .003 & & \\
\hline N of Valid Cases & 72 & & & & \\
\hline \multicolumn{6}{|l|}{ Socialization } \\
\hline Chi-Square Tests & Value & $\mathrm{df}$ & \multicolumn{3}{|c|}{ Asymptotic Significance (2-sided) } \\
\hline Pearson Chi-Square & $18.338^{\mathrm{a}}$ & 2 & \multicolumn{3}{|c|}{.000} \\
\hline Likelihood Ratio & 22.593 & 2 & \multicolumn{3}{|c|}{.000} \\
\hline Linear-by-Linear Association & 17.913 & 1 & \multicolumn{3}{|c|}{.000} \\
\hline $\mathrm{N}$ of Valid Cases & 72 & & & & \\
\hline \multicolumn{6}{|l|}{ g. Accompaniment } \\
\hline Chi-Square Tests & Value & df & \multicolumn{3}{|c|}{ Asymptotic Significance (2-sided) } \\
\hline Pearson Chi-Square & $18.338^{\mathrm{a}}$ & 2 & \multicolumn{3}{|c|}{.000} \\
\hline Likelihood Ratio & 22.593 & 2 & \multicolumn{3}{|c|}{.000} \\
\hline Linear-by-Linear Association & 17.913 & 1 & \multicolumn{3}{|c|}{.000} \\
\hline $\mathrm{N}$ of Valid Cases & 72 & & & & \\
\hline
\end{tabular}

h. Open government

\begin{tabular}{lccc}
\hline \multicolumn{1}{c}{ Chi-Square Tests } & Value & df & Asymptotic Significance (2-sided) \\
\hline Pearson Chi-Square & $12.215^{\mathrm{a}}$ & 2 & .002 \\
Likelihood Ratio & 13.688 & 2 & .001 \\
Linear-by-Linear Association & 11.786 & 1 & .001 \\
\hline N of Valid Cases & 72 & & \\
\hline i. $\quad$ Program suitability & & & Asymptotic Significance (2-sided) \\
\hline$\quad \quad$ Chi-Square Tests & Value & df & .000 \\
\hline Pearson Chi-Square & $34.940^{\mathrm{a}}$ & 2 & .000 \\
Likelihood Ratio & 44.113 & 2 & .000 \\
Linear-by-Linear Association & 31.422 & 1 & \\
\hline N of Valid Cases & 72 & & Asymptotic Significance (2-sided) \\
\hline$\quad$ j. Benefits & & & .000 \\
$\quad$ Chi-Square Tests & Value & df & .000 \\
\hline Pearson Chi-Square & $35.332^{\mathrm{a}}$ & 2 & .000 \\
Likelihood Ratio & 42.929 & 2 & \\
Linear-by-Linear Association & 30.051 & 1 & \\
\hline N of Valid Cases & 72 & & \\
\hline
\end{tabular}


k. Distance

\begin{tabular}{lccc}
\hline \multicolumn{1}{c}{ Chi-Square Tests } & Value & df & Asymptotic Significance (2-sided) \\
\hline Pearson Chi-Square & $5.576^{\mathrm{a}}$ & 2 & .062 \\
Likelihood Ratio & 5.349 & 2 & .069 \\
Linear-by-Linear Association & 2.668 & 1 & .102 \\
\hline N of Valid Cases & 72 & & \\
\hline
\end{tabular}

Socialization and program suitability have a significant relationship with the level of participation. In addition, program suitability also has a relationship with the level of participation. The suitability of this program also describes the communication process and the openness of the government in accommodating problems that exist in society. The community tends to participate in programs in accordance with the wishes of the community. Program suitability relates to community involvement since program planning so that the program to be implemented is the result of aspirations and in accordance with community needs. The suitability of the program will be able to overcome problems that exist in the community. Thus the community also benefits from the program so that people have high enthusiasm to participate in the implementation of development programs.

\section{Conclusion}

Based on the research results, it can be concluded that:

a. Based on the schalogram analysis of villages in the agropolitan area in Trenggalek Regency, it is obtained a hierarchy of regions in the agropolitan area in Trenggalek Regency, so that the villages of Tasikmadu, Pule, Jombok and Sumurup are the centers of growth and service centers while the development areas of Karanggandu, Prigi, Watulimo Villages. Sawahan, Watuagung, Sidomulyo, Tanggaran, and Dompyong as Order 2. Order 2 is an agropolitan area. While other development areas, namely the Dukuh, Slawe, Gemaharjo, Pakel, Ngembel, Puyung, Joho, Kembangan, Pakel, Masaran, Sengon, Srabah, Surenlor and Botoputih development areas are hinterland areas.

b. Based on the results of the LQ analysis, the agropolitan area in Trenggalek Regency has 34 (thirteen) commodities that have an LQ value of more than 1 , namely:
1) Food crops sub-sector: Rice, corn, soybeans and cassava.

2) Vegetable sub-sector: Leeks, potatoes, mustard greens, long beans, large chilies, cayenne pepper, green beans and chayote.

3) Fruit crop subsectors: avocado, star fruit, duku, durian, guava, water guava, siem orange, big orange, mangosteen, jackfruit, papaya, rambutan, salak, sapodilla and soursop.

4) Plantation sub-sector: Patchouli, sugar cane, cocoa, cloves, coffee, vanilla and cottonwood.

5) The level of public perception of the agropolitan program is relatively poor. There is a relationship between the location where the farmers live and the commodities cultivated with the level of perception. Farmers who are in growth centers and cultivate superior commodities tend to have a better perception.

6) The level of community participation in agropolitan programs is relatively low. The intrinsic factors that have a real influence on the level of participation are income and land area, while the extrinsic factors are socialization, assistance, openness of government, program suitability and benefits. Increasing community participation can be done by improving the factors that have a real influence.

Based on the results of this study, in the development of the agropolitan area in Trenggalek Regency, it is necessary to increase community participation so that there is no bias in physical development, especially by increasing socialization to the community and accommodating community aspirations so that the program of activities is in accordance with the needs and is able to solve problems in society. 


\section{References}

Baskoro. 2007. Analisis Pewilayahan, Hirarki, Komoditas Unggulan dan Partisipasi Masyarakat Pada Kawasan Agropolitan (Studi Kasus di Bungakondang Kabupaten Purbalingga). Tesis tidak di terbitkan. Bogor. Sekolah Pascasarjana IPB.

Brata. 2013. Partisipasi Masyarakat Petani Dalam Pengembangan Kawasan Agropolitan di Kecamatan Tugu Mulyo Kabupaten Musi Rawas. Tesis tidak diterbitkan. FP UNIB.

[Bappeda] Badan Perencanaan Pembangunan Daerah Kabupaten Trenggalek. 2018. Rencana Tata Ruang dan Wilayah Kabupaten Trenggalek Tahun 2008-2018. Trenggalek: Bappeda Kab. Trenggalek.

Citraningrum. 2009. Partisipasi Masyarakat dalam Program Pengembangan Kawasan Agropolitan Desa Beji Harjo Kabupaten Gunung Kidul. Majalah Geografi Indonesia, Volume 7, nomor 2.

Efendi. 2017. Partisipasi Masyarakat Dalam Program Pengembangan Kawasan Agropolitan (Kasus Desa Srimartani, Kecamatan Piyungan, Kabupaten Bantul). Jurnal Bumi Indonesia, Vol 6 No. 1.

Endaryanto T. 1999. Persepsi dan Partisipasi Masyarakat yang Terlibat dan Tidak terlibat Program Makanan Tambahan Anak Sekolah (PMT-AS). [thesis]. Bogor: Program Pascasarjana, Institut Pertanian Begor.

Harahap MK. 2001. Kajian Partisipasi Masyarakat dalam Pengelolaan Rutan Mangrove [Thesis]. Bogor: Program Pascasarjana, Institut Pertanian Bogor.

Lestari. 2019. Partisipasi Masyarakat Dalam Pengembangan Kawasan Agropolitan Program Padat Karya Tunai di Desa Tasikmadu Kecamatan Palang Kabupaten Tuban. Journal of Agricultural Extention 43(2).

Pujo. 2003. Partisipasi Masyarakat pada Program Kehutanan Sosial di Perum Perhutani Unit III Jawa Barat (thesis\}. Bogor: Program Pascasarjana, Institut Pertanian Bogor.
Yulida R. 2002. Partisipasi Petani terhadap Program Sistem Pertanian Terpadu (thesis). Bogor: Program Pascasarjana, Institut Pertanian Bogor. 